\title{
The world of gods and the body of man: mythological origins of modern anatomical terms*
}

\author{
Axel Karenberg \\ Institute for the History of Medicine and Medical Ethics, University of Cologne, Cologne, Germany
}

\begin{abstract}
A number of designations for human body structures derive from classical mythology. These eponyms in the vocabulary of macroscopic anatomy and teratology (e.g., Achilles tendon, Ammon's horn, cyclopia and sirenomelia) have not been systematically investigated until now. This paper therefore provides an overview of this fringe component of anatomical vocabulary, analyzes the medical history of several terms and formulates hypotheses as to why such creative etymologies have come into being. In addition to relevant texts on ancient mythology and medicine, a range of anatomical textbooks from the early modern period will be analyzed. Between the 16th and the 20th centuries some 15 figures from Egyptian, Greek and Roman literature made their way into the nomenclature of the morphological sciences. Today a few of these expressions remain official anatomical terminology (e.g., atlas, hymen, iris) and can be encountered in clinical use (hermaphroditism, janiceps, satyr ear, Cupid's bow) while others have been eliminated (nymphs, mount of Venus). The choice of these designations for anatomical structures has often been similarity of form or, less commonly, analogies in function. Classical eponyms have gained acceptance on account of their succinctness, conciseness and scholarly veneer. Finally, this vocabulary shares its origin with other relevant medical terminology. In anatomy classes mythological designations and their origins can serve as a point of departure for digressions into literary, art and medical history in order to provide an understanding of cultural traditions and enhance education.
\end{abstract}

Key words: anatomy/history; ancient; history; medicine in art; mythology; terminology as topic

Anatomy 2012-2013;6-7:7-22, (c) 2012-2013 TSACA

\section{Introduction}

For centuries the Greek and Roman gods have lived on not only in museums and libraries, but also in the language of anatomy. Despite all nomenclature reforms their names continue to appear as terms for normal structures and congenital malformations. Yet are these mythological figures really part of medicine's oft-cited cultural heritage? Do they actually testify to the memory of forgotten ancient legends and tales?

Granted, terms such as Achilles tendon and hermaphrodite may count upon recognition for their origin. Yet who would have guessed that the modern term lymph is linguis- tically and intrinsically related to the ancient nymphs? Who would have thought that sirenomelia has anything to do with the legendary creatures from Homer's Odyssey? Who could claim to know when and why these mythological creatures were incorporated into medical language?

To date these kinds of questions have not been systematically investigated. Scattered hints can be found in Hyrtl's "History of anatomical names" ${ }^{\text {"[1] }}$ and in a subsequent multi-volume series, ${ }^{[2]}$ but neither Anglo-American nor French literature offer information regarding etymology. ${ }^{[3-5]}$ This provides the opportunity to present to anatomists a facet of their professional language with which they might not be familiar. Furthermore, this paper

*This paper is dedicated to Fuirgen Koebke, emeritus professor and former head of the Anatomical Institute of the University of Cologne, Germany, Honored Member of the Turkish Society of Anatomy and Clinical Anatomy and Scientific Advisory Board Member of this journal, who tragically passed away on 23rd of February 2012 in Cologne. 
will demonstrate that engaging the history of language and classical mythology can be just as didactic and entertaining for students.

From a linguistic perspective mythologically inspired expressions are considered eponyms. ${ }^{[6]}$ Within the clinical vocabulary we have identified some 30 terms of this kind the most common of which include medusa bead, Proteus, morphine and atropine. By contrast, anatomical and teratological vocabularies boast only a dozen or so terms with this background. This group will be the focus of the following remarks. In each section only that part of mythological tradition will be considered which is crucial for the comprehension of the anatomical term. Thereafter we shall examine when and why a mythological figure was brought into scientific parlance and the subsequent fate of the term.

\section{Between Heaven and Earth: Mythological and Anatomical Atlas}

In the 8th century BC the Greek poet Hesiod related the story of Zeus who had to fight the Titans and their allies during his battle for world domination. The father of gods was victorious and sentenced one of the defeat Titans, the gigantic Atlas, "to uphold the wide heaven with unwearying head and arms" (Theogony, 519). Ever since then this legendary figure has stood at the western edge of the world where day and night meet, at an ocean which would later be named after him: the Atlantic.

Yet it was a long path that took the mythological bearer of heaven to the world of anatomy. The first steps were taken by ancient authors. In the first century $\mathrm{AD}$ the Roman encyclopedist Pliny the Elder employed the diminutive form atlantion -little atlas- curiously for the uppermost cervical segment of the hyena (Natural History, 28, 99). About a hundred years later Julius Pollux, a recognized expert in ancient terminology, used the term atlas to designate the seventh vertebra in humans. According to Pollux, this bone permitted the carrying of burdens on the shoulders (Onomasticon, 2, 132). This definition remained in force for a long time. The famed Renaissance anatomist Andreas Vesalius also mentioned the mythological hero only in passing in his seminal work of 1543 (Fabrica, p. 167).

Despite this, by about 1600 the term atlas was definitively established as referring to the uppermost vertebra. How this came to pass can only be guessed. Of course, hero and vertebra are linked as both must continuously carry a heavy load. Moreover, anatomical wordsmiths were probably alluding to the contemporary idea that Atlas himself created the first celestial sphere, an argu-

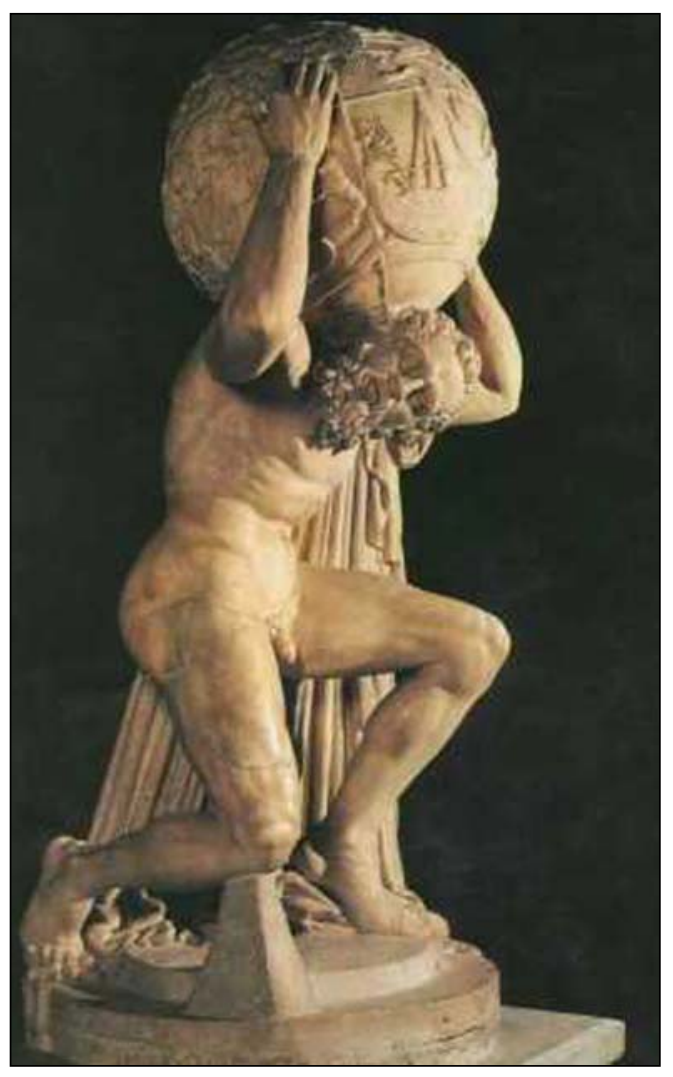

Figure 1. Atlas Farnese. Marble sculpture, circa 150 AD (courtesy of Naples National Archeological Museum). 
ment supported by the geometric analogy between the rotund heaven and the head (Figure 1). It is also possible that anatomical scholars used this trenchant appellation in order to allude to the very close connection between the uppermost cervical segment with both the vertebral column as well as the skull: the mythological warrior likewise occupied an absolutely essential position between earth and heaven. As in many similar cases, those involved gave no indication of their motives. From that point on, however, the anatomical atlas remained inviolate in all dictionaries. It was entered unchanged in the vocabulary of Terminologia Anatomica (TA) in 1998. ${ }^{[7]}$

\section{The Weakest Point of a Strong Man: The Achilles Tendon}

In many western languages the expression Achilles heel exists for the sore spot or weak side of a person. For this reason, if no other, the legend of Achilles, the most beautiful and bravest of the Greeks who attacked Troy, is known by many. The decisive episode took place in his youth: in order to make him invulnerable his mother Thetis immersed him in the waters of the underground river Styx. She held him by his right heel which consequently remained dry, however (Figure 2). This is why

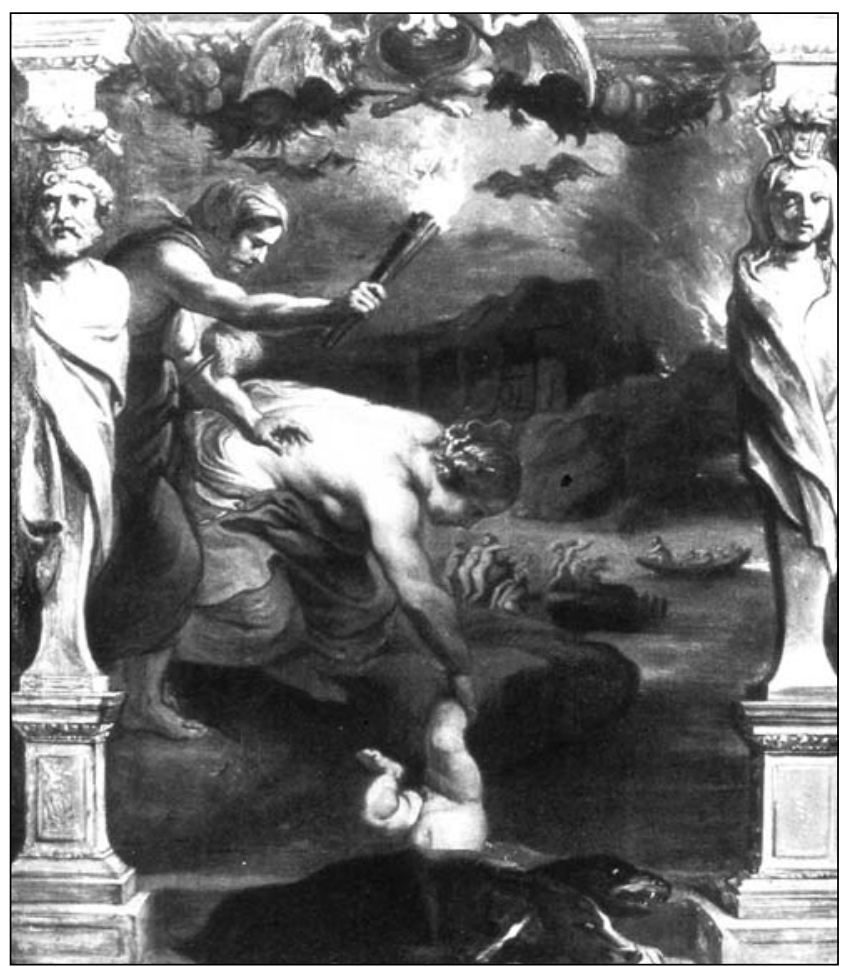

Figure 2. Rubens: Thetis dipping Achilles into the river Styx. Oil on canvas, ca. 1630 (courtesy of Museum Boijmans van Beuningen, Rotterdam) the warrior was exclusively vulnerable at this point. It was there that Paris' deadly arrow found its mark.

Yet the circumstances under which the young hero entered the vocabulary of medicine are surrounded by a mysterious aura. What is certain is that Philip Verheyen, who held a chair in anatomy at the Flemish University of Louvain, played a key role. An initial version of the story has it that he had to have a leg amputated after which he dropped his theological studies in favor of medicine. ${ }^{[8]}$ Another version of the story has it that he preserved the amputated limb and when examining his own leg got the idea of naming the strongest tendon in the human body after the weakest part of the strongest Greek fighter (Figure 3). The most likely case is that both of these versions are incorrect as modern biographies do not mention the procedure that maimed him. ${ }^{[9]}$ Moreover, in his famous 1693 textbook "Corporis Humani Anatomiae" Verheyen wrote quite demurely that the structure occasionally had been called chorda Achillis by some colleagues. Shortly thereafter the German surgeon Lorenz Heister conclusively transformed chorda into tendo Achillis.

When in 1895 the Basle Nomina Anatomica (BNA) was dissociated with proper names, the tendon of the triceps surae mutated into the linguistically anemic calcaneal

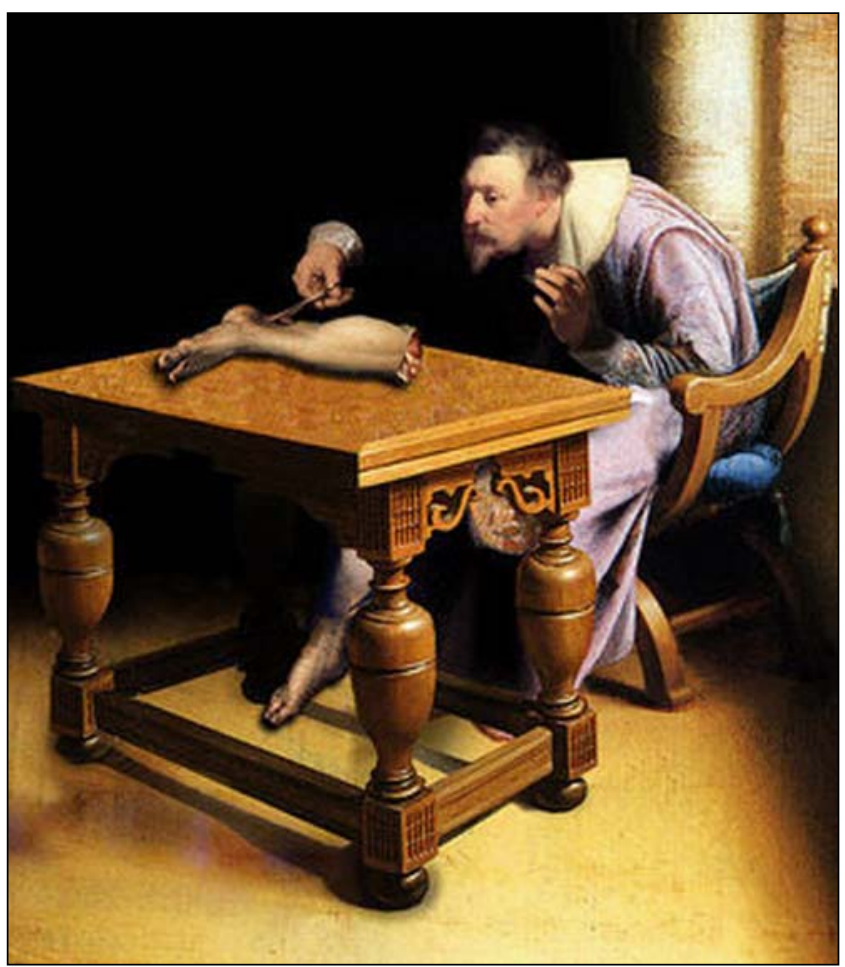

Figure 3. Anonymous: Philip Verheyen dissecting his amputated left leg. Collection Pieter DeHeyde ${ }^{[9]}$ Phantasy or reality? 
tendon. Despite this clinicians around the globe adhered to the eponym and insisted on their Achilles tendon reflex and Achilles tendon rupture. In a reversal of the historical tendency, reverence to the Homeric hero was once again evident in the $1998 \mathrm{TA}$ in form of a reference - albeit only in the appended index of eponyms. ${ }^{[7]}$

\section{Water and Madness: The Nymph and the Lymph}

A textbook example of the serpentine linguistic history that has produced anatomical terms can be seen with the nymphs. These were girl-shaped figures from Greek folk belief who sang, danced and played music for the "real" gods and who lived in wells, rivers and seas (Figure 4). We are concerned here with these semi-divine daughters of Zeus in relation to the human lymph system (and again below as regards their relationship to the sexual organs).

In both Homer and the Attic tragic tradition the Greek word nymphe appears with the meanings of a mermaid and a young woman. ${ }^{[10]}$ In contrast, lympha does not appear in Ancient Greek but is a Latin word derived from nymphe. This exchange of the consonants $\mathrm{N}$ and $\mathrm{L}$ is not uncommon. Further evidence for this derivation is supplied by the Roman grammarian Sextus Pompeius Festus in the second century $\mathrm{AD}$ who observed: "The lymphae (waters) are named after the nymphae (water spirits)." ${ }^{[2]}$

The Latin noun lympha meant "clear and pure source of water". Astonishingly, the related adjective lymphaticus meant something completely different, namely "raving" or "crazy". This can be traced back to the legend that he who gazes upon the very feminine, enchanting and sensuous Nymphs will go insane. When in the $17^{\text {th }}$ century the delicate canals of the third vascular system were discovered during dissection anatomists nevertheless continued to speak of lymphatic structures. In Baroque-era Latin the meaning of this adjective changed to meaning "pertaining to water" in the sense of the original word "water-clear liquid". Numerous linguistic derivatives, such as lymphatic plexus and lymphatic node, came later and were codified in various steps within the maturing nomenclature.

\section{Between Lips and Loins: Cupid and His Bow}

It was in 1960 that the phrase Cupid's bow was first used to describe the double curve of the upper lip. ${ }^{[11]}$ This term is favored more by pediatricians and oral surgeons than by anatomists, particularly since it is not part of the official TA. As in other cases, analogy of form is here the

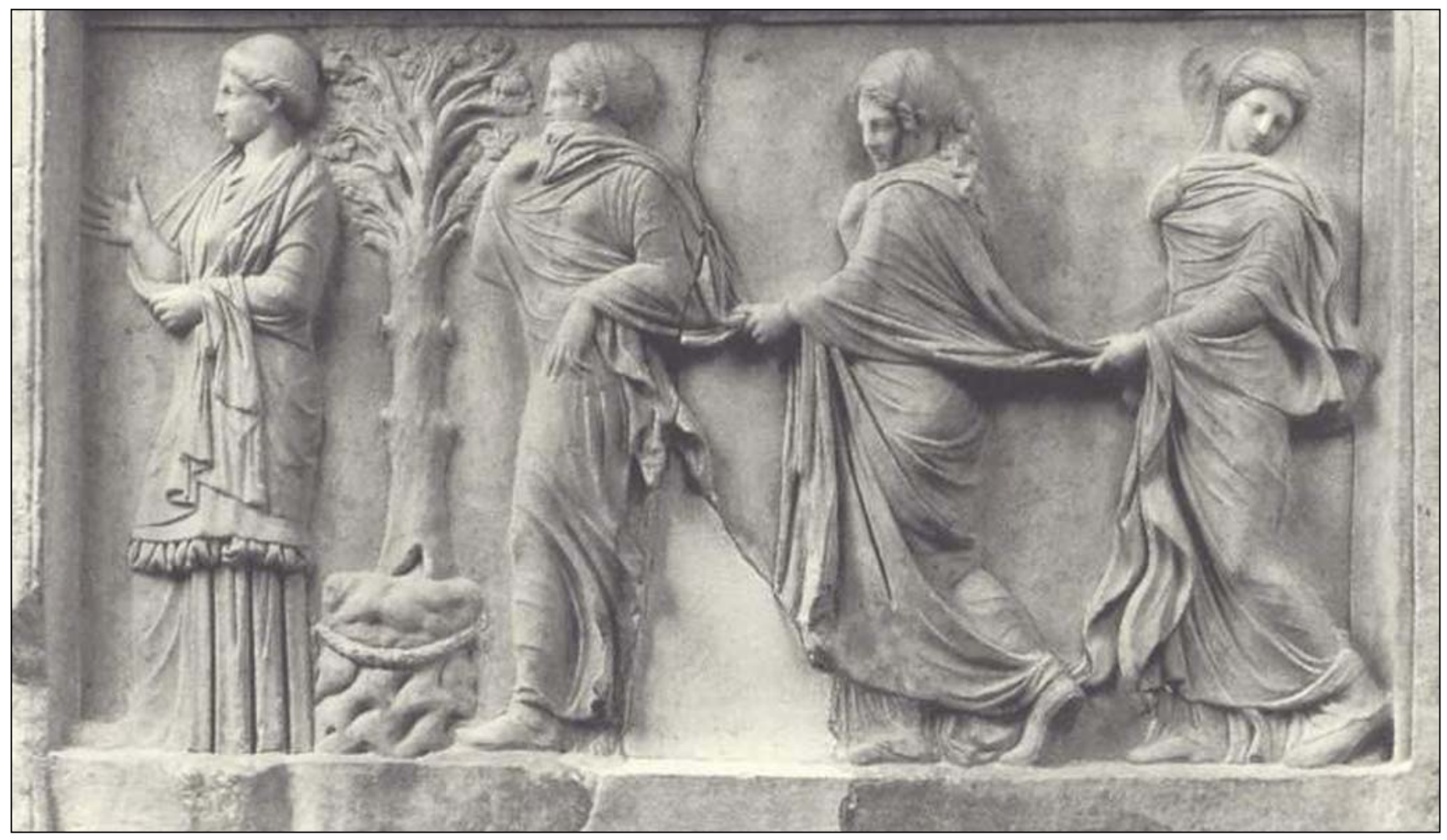

Figure 4. The dance of the nymphs. Votive relief, circa 150 AD (courtesy of Piraeus Archeological Museum). 
Figure 5. Cupid and his bow. Roman marble statue (courtesy of Capitoline Museums, Rome)

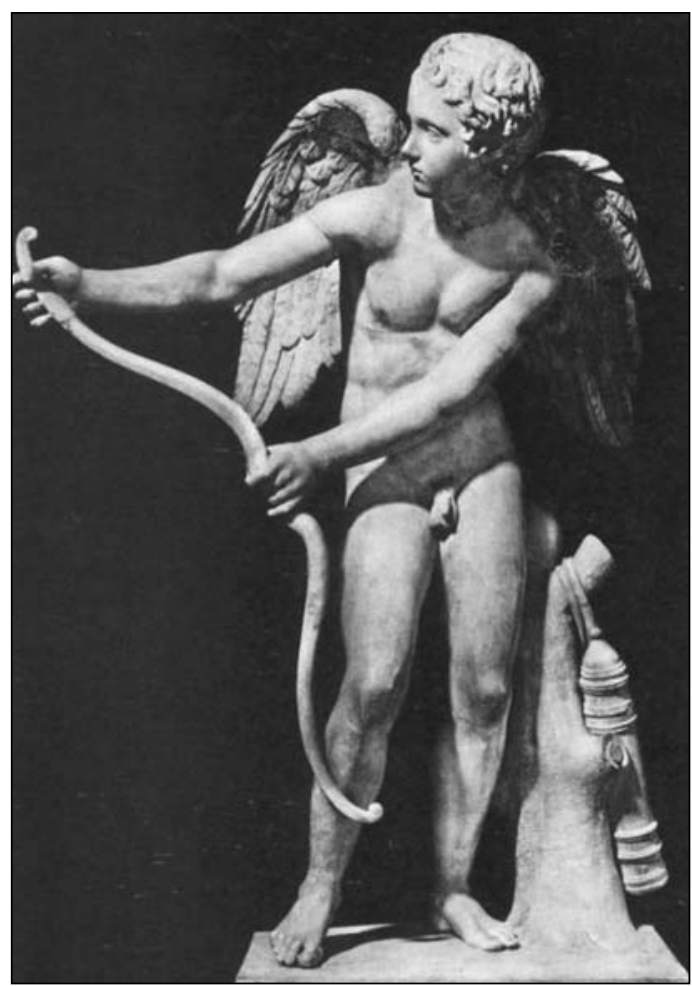

crucial link between the world of gods and the human body: the weapon of the Roman god of love and the upper lip (Figure 5). The hand-grip of the bow corresponds to the narrow, azygous, central part of the upper lip which rises vertically via a groove to the nose; the parts of the lip to the left and right that bend outwards represent the convex arms of the bow. Its "back" is turned upwards, its "belly" points toward the mouth.

From a historical perspective this designation is eminently fitting as phylogenetically as well as ontogenetically the mouth is associated with, for example, feeding and kissing. In many cultures the mouth and lips are considered "erogenous zones", named after Eros, the Greek pre- cursor to Cupid. In Hellenic culture it was far less the upper lip than the upper half of the vertical groove mentioned above -known as the philtron - that was considered the crucial mark of beauty for both sexes. Thus the recently introduced anatomical meaning for Cupid's bow is part of a more than two thousand year cultural tradition.

Since the mid-1970s this expression has also been given a radiological meaning. As the inferior end plates of the lower lumbar vertebrae have a slightly curved contour in frontal projection (Figure 6), radiologists refer to this variation as Cupid's bow. ${ }^{[12]}$ Given the historical description provided above, the application of this term to this body part seems misplaced however.

Figure 6. Radiological "Cupid's bow" contour of a lower lumbar vertebra in anteroposterior tomogram. ${ }^{[12]}$

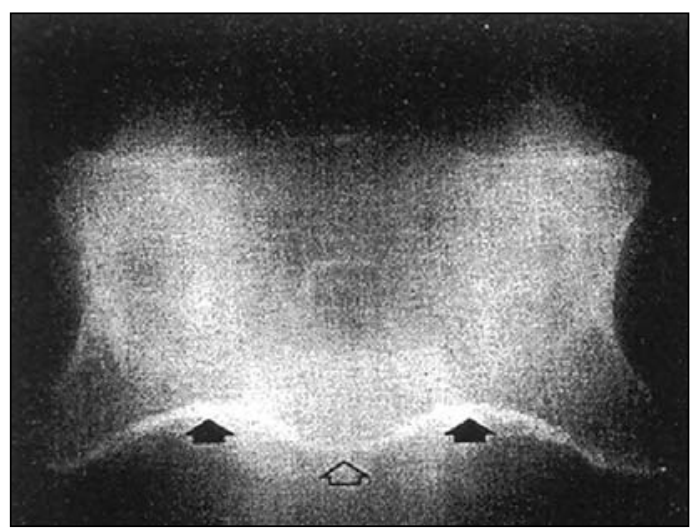




\section{Hymanaeus and Hymen: A Masculine Name for a Female Structure}

Mythological figures have always played a prominent role in the description of sexual abnormalities. Ancient physicians employed satyriasis to describe an excessive sexual desire and priapism to designate the persistent, non-sexual and often painful erection of the virile member. Much later psychoanalysis also tapped this source for its new concepts: Oedipus complex, narcissism and Electra complex represent the best known examples. Thus it is not surprising that this kind of nomenclature plays a certain role in the terminology of the sexual organs (especially those of women).

Yet some of these terms have had a convoluted development including, for example, the male noun bymen On one hand it simply means a membrane, on the other the Greeks also called a wedding song and the god of marriage Hymen or Hymenaios. ${ }^{[13]}$ This Hymenaios was celebrated by the poet Pindar around $500 \mathrm{BC}$ as a young man who died on his wedding night in his wedding chamber (Figure 7). The decisive question is then: when and where did these two historical meanings merge?

The structure known today as the anatomical hymen had no name in any Greek dialect. Some physicians even contended the existence of the fold of mucous membrane in the vaginal introitus. Classical Latin as well employed euphemisms, e.g., "flos virginitatis". In the sense of a vaginal membrane whose tearing during first coitus ends maidenhood the word bymen first appeared in the $4^{\text {th }}$ century $\mathrm{AD}$ in two Latin grammars only immediately thereafter to fade into obscurity again. ${ }^{[2]}$ Two $16^{\text {th }}$ century Italian anatomists mentioned the expression in their Latin texts without appending anything regarding the term's origin; ${ }^{[14]}$ at this point in time its use was thus not definitively established. The membrane and its name were rediscovered around 1700 when physicians and forensic pathologists began to perform tests of virginity on a broader scale. ${ }^{[15]}$ Thus the masculine marriage god of the Greeks made a decisive contribution to the naming of a uniquely feminine anatomical structure - even if this can only be proven indirectly.

\section{Divine Grace in Science, Esoterism and Literature: The Mons Veneris}

At first glance the linguistic role of the Roman goddess of love Venus appears to be much clearer (Figure 8). The adjective venereus used to mean "relating to physical love" or "sexual" in clinical and everyday language. As the personification of grace and carnal desire, Venus was equated with the Greek goddess Aphrodite early on; this latter figure was known to pharmaceutical terminology since at least 1750 via the word aphrodisiac.

During the Renaissance the adjectives mentioned above were used to characterize the new sexually transmitted disease syphilis as "Morbus venereus" or "Lues

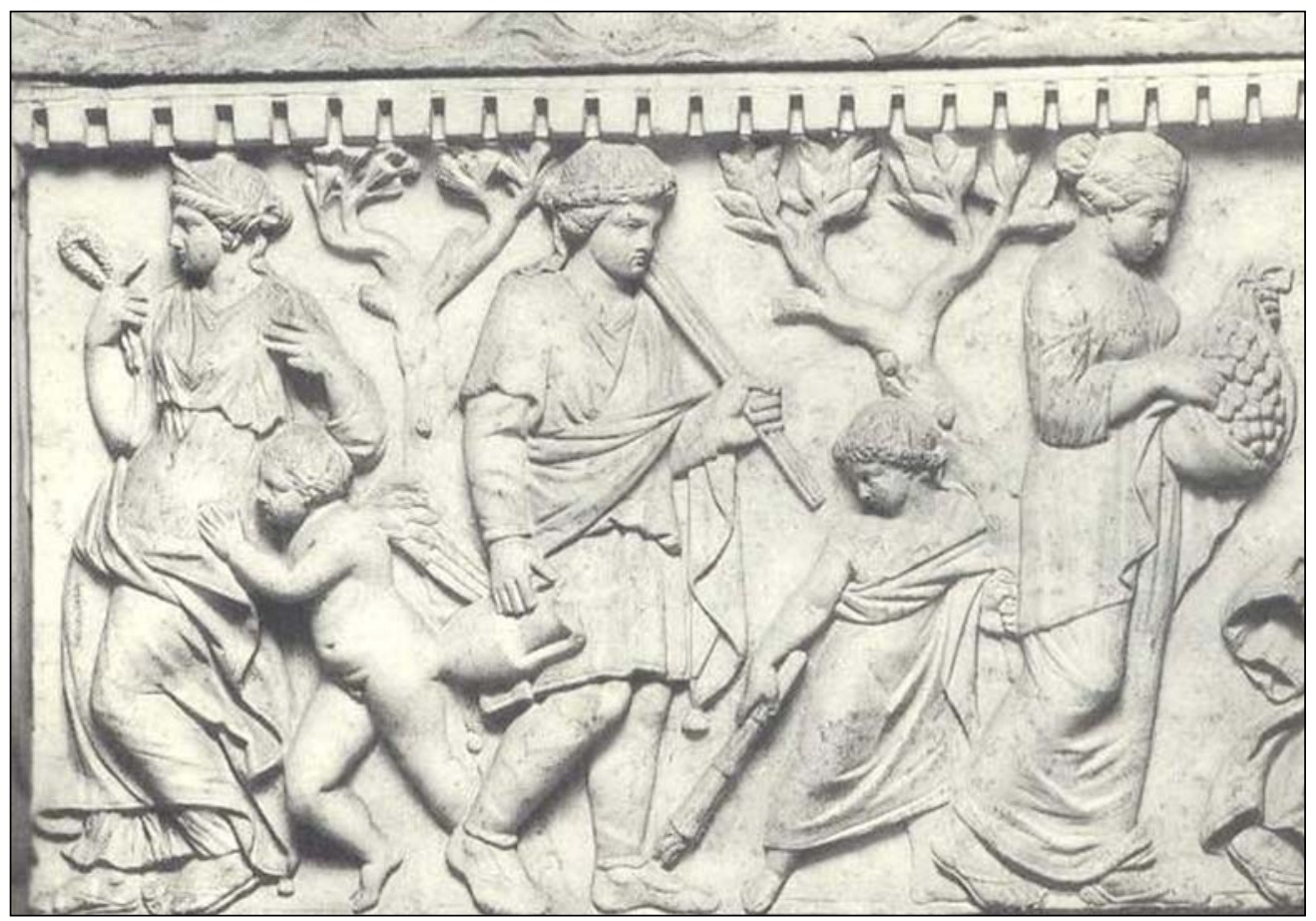

Figure 7. Hymenaios (middle). Marble relief on a stone sarcophagus, circa 100 AD (courtesy of Collection Villa Albani, Rome). 
venerea". Sometime in the $17^{\text {th }}$ century anatomists began using the expression mons Veneris to denote a subcutaneous cushion of fat located above the female pubic bone. Possibly this appellation was also the product of the medieval legend in which a woman ruled a kingdom of greatest sensual enjoyment inside a "magic mountain". The career of the mount of Venus in anatomical vocabulary was, however, comparatively short; the mythological expression was not listed in the BNA. ${ }^{[2]}$ In addition to the aversion of the reformers of the day to using proper names, a second argument was of relevance: palmistry, which was quite popular then, already employed the term mount of Venus to designate the thenar and regarded its prominence as an indication of amorous adventures. For that reason anatomists chose the more neutral mons pubis in order to establish a scientific boundary and restore linguistic clarity.

Around the fin-de-siècle Venus remained employed in medicine principally in the designation of "venereology". Of course the goddess of love also worked her way into the everyday language of the Latin countries: the "dies Veneris" is the origin of the French vendredi, the Spanish viernes and the Italian venerdì.

\section{A Bride's Hidden Body Part: The Anatomical Nymph}

Due attention has been paid above to the etymology of lymph in the Greek nymphs. There is yet another part of the body which owes its name to these semi-divine maidens and their erotic aura, although it is not often used presently.

Once again the anatomical application began in ancient times. The Greek word nymphe not only meant "water elf" or "maiden", but also "veiled bride". Aristotle and Pliny the Elder employed this word to designate pupated insect larvae as nymphs. ${ }^{[1]}$ This metaphor was used in a secondary fashion as well, namely for a hidden part of the female genitalia. In ancient anatomical vocabulary the clitoris represented the morphological nymph as is testified in the works of physicians Rufus of Ephesus, Galen and the linguistic expert Julius Pollux. ${ }^{[13]}$ It was this meaning which attracted the attention of modern psychiatrists who sought an etiquette for the supposed increased sexual drive of women: nymphomania.

In anatomy, by contrast, around 1600 a singular was turned double when applied to the labia minora. Whether this redefinition was made out of ignorance or on account of a misinterpretation of the Greek writings is difficult to say. The Dutch anatomist Adriaan van de Spiegel explained in his textbook that this body part was so designated because it was "the first to admit the bridegroom" and "channeled the flow of urine". ${ }^{[2]}$ This is what it was called until 1895 when this mythologicallyinspired tradition was torn asunder, for in that year the BNA dropped the suggestive nymphs in favor of the more sober labia minora.

\section{A Greek Mythical Creature and an Egyptian God: Hippocampus and Ammon's Horn}

Anatomical wordsmiths often called upon the animal world when especially incisive structural comparisons could be made. This striving after figurative denominations explains why the central nervous system has a "bird's claw" (calcarine spur) and a "small brain worm" (vermis of cerebellum).

The Bolognese anatomist Giuseppe Cesare Aranzi employed a similar metaphor in 1587 when during a brain dissection he came across some remarkable formations at the base of the lateral ventricle. To the left and right of the median he found a large and somewhat rolled up bulge which broadened toward the front and was divided by parallel grooves into toe-like rises. "This recalls the image of a Hippocampus, that is, of a little sea-horse", the researcher noted to which he added: "Rather, perhaps, it suggests the form of a white silk-worm." ${ }^{[16]}$ $\mathrm{He}$ and posterity decided for the shorter and more charming hippocampus otherwise this structure would be known today as "Bombycinus vermis."

We may presume that here too a mythological context played a certain role. In ancient Greece

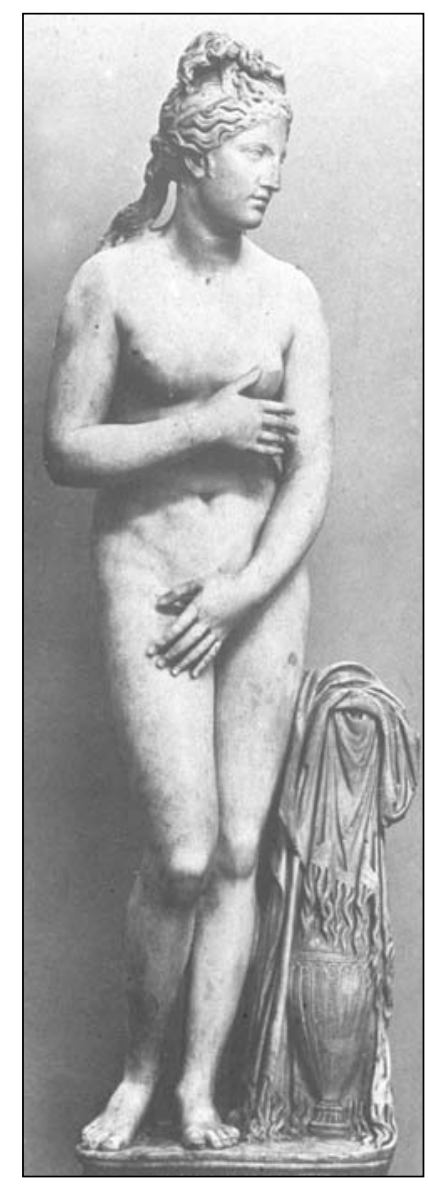


hippokampos also referred to a fantasy horse whose upper half resembled a whale or a monster (Figure 9); the chimera pulled the sea god Poseidon's chariot through the waves. This tradition was captured by Renaissance artists who often represented the mythical horse as riding upon gems or fountains; one such statue stands in Bologna, near where Aranzi worked. Could the anatomist be deeply inspired by this tradition?

In contrast, one figure that most assuredly belongs to the world of gods is the ancient Egyptian Amun. His name first surfaces in brain terminology in 1742 as a designation for the sinuous part of the cerebral hippocampus described above. ${ }^{[18]}$ Statues of the Pharaonic god king were characterized by a defining form: the immortal's head was adorned with mighty, curved ram's horns (Figure 10). This attribute made Amun (in Greek Ammon) the indisputable patron for spiral and coil formations - equally for the Ammon's horn in the brain as for the paleontologists' ammonites.

\section{Divine Eyes and Bestial Ears: Iris and Satyrs}

The fine structure of the sensory organs has generated few spectacular names for anatomical structures. Only two expressions from this area have even a remote link with mythology.

In both the Greek and Roman pantheons Iris personifies the rainbow. The colorful natural phenomenon helped the goddess perform her duties as messenger, principally for the queen goddess Hera (Figure 11). According to folk belief, a long, beautiful rainbow showed mankind Iris' path from heaven to earth. The Roman poet Ovid put it this way in his famous Metamorphoses (Book 11: 589-591):
"Iris donned her thousand-colored robe, and, tracing her watery bow on the sky, she searched out, as ordered, the palace of that king, hid under cloud."

Ancient sciences used iris firstly as a botanical term: "Their blossom is a multicolored splendor, hence its name", noted Pliny the Elder (Natural History, 21, 41). Only in around $100 \mathrm{AD}$ did anatomy connect with the human visual organ. Rufus of Ephesus described the iris as "that (membrane) which stretches from the pupil to the white of the eyes" ${ }^{[2]}$ This passage is the first evidence for the definition of the iris we accept as valid today.

It would be erroneous, however, to date the origin of our present term to this point, for its subsequent linguistic development is anything but straightforward. Within anatomical terminology the word was used to designate the iris of the eye, but it also had other meanings. It was only in the $18^{\text {th }}$ century that the meaning of iris was restricted to the colored area between the anterior and posterior chamber of the eyeball. Thereafter the Greek word iris (and the genitive irid/os) were the source of a number of clinical terms, the most common of which is a linguistic surprise. Because the technical term for inflammation ordinarily is derived from the stem of the original word, the corresponding pathology of the iris would correctly be "iriditis" but instead the false construction "iritis" is used!

In the broadest sense "satyr" can also be counted as an example of a morphological form variant. These Greek deities of the woods and fields belonged to Dionysus' entourage and distinguished themselves with a virtually animalistic lustfulness and fertility. They also boasted a peculiarity on their heads: their ears were tapered and positioned unusually widely (Figure 12).

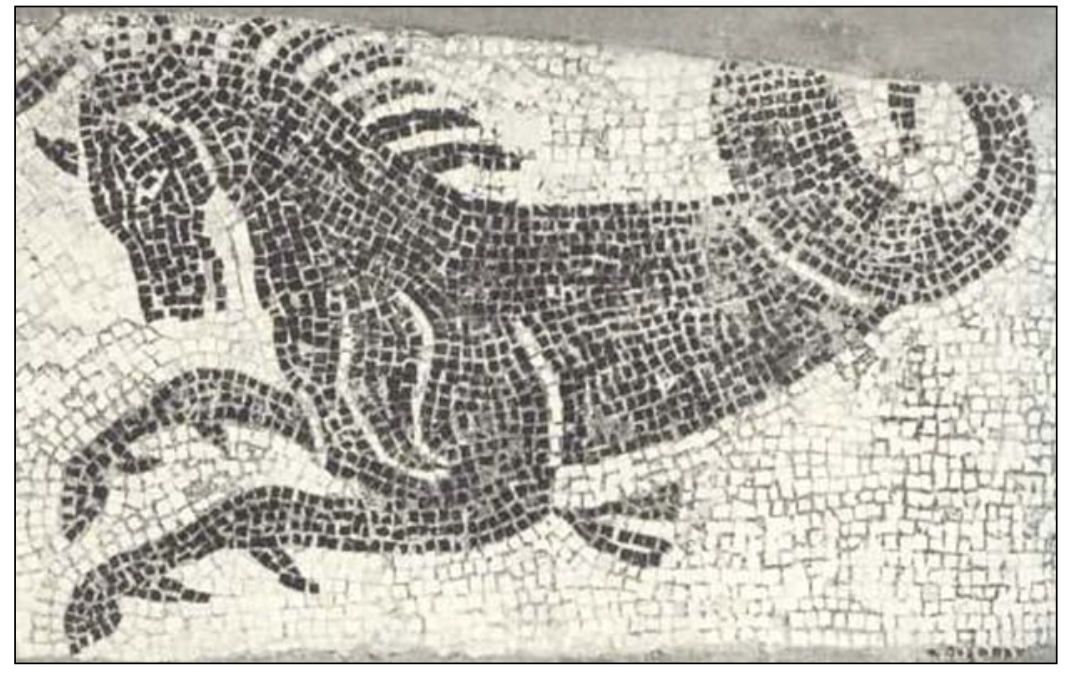

Figure 9. Hippocampus. Mosaic, 2nd-3rd c. AD (courtesy Museum of Navarre, Pamplona). 
Figure 10. Head of Ammon. Sculpture from black diorite, clearly of Egyptian origin (courtesy of Archeological Museum of Istanbul)

Congenital deformations can produce similarly misshapen auricles and for this reason are sometimes known in medical jargon as "satyr ears". ${ }^{[4]}$

\section{Excursus: Biblical Adam and His Apple}

Biblical stories are employed far less frequently than Greek or Roman legends by medical science as a source for terminology for a simple reason: even in ancient

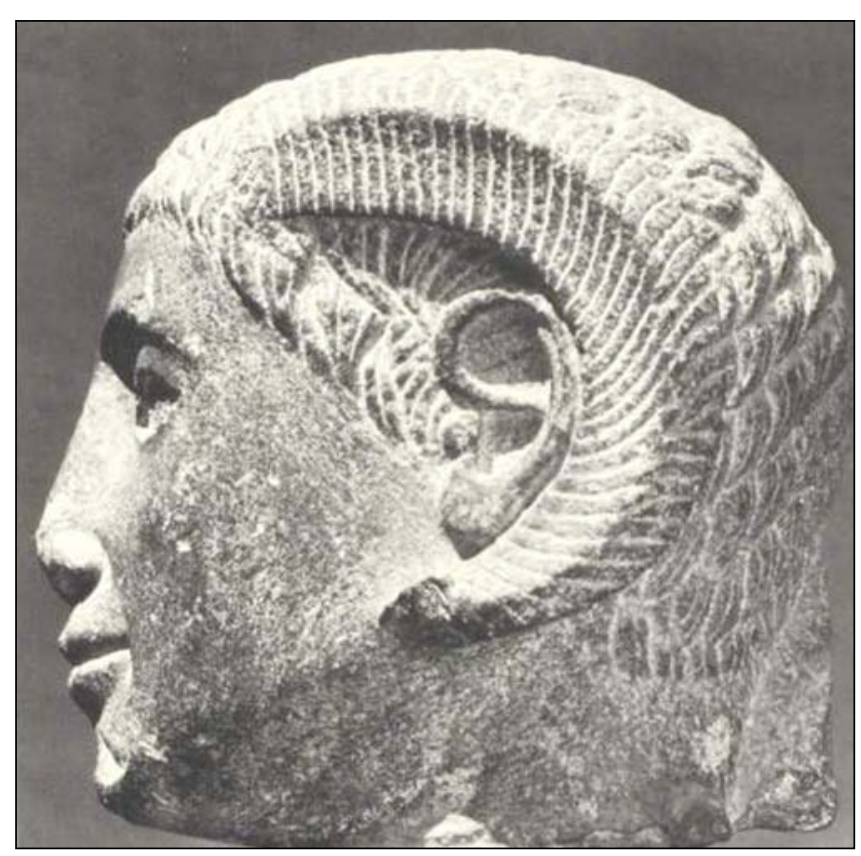

times the deeds and experiences of the classical gods were considered cute anecdotes in which almost nobody believed anymore, but to employ figures from the Book of Books contained the danger of committing blasphemy. This is why modern anatomical nomenclature includes merely a single expression of Biblical origin. However its development is indeed worth in-depth treatment.

Figure 11. Iris (right) und Hera. Jug, circa 480 BC (courtesy of Museum of Art, Rhode Island School of Design, Providence).

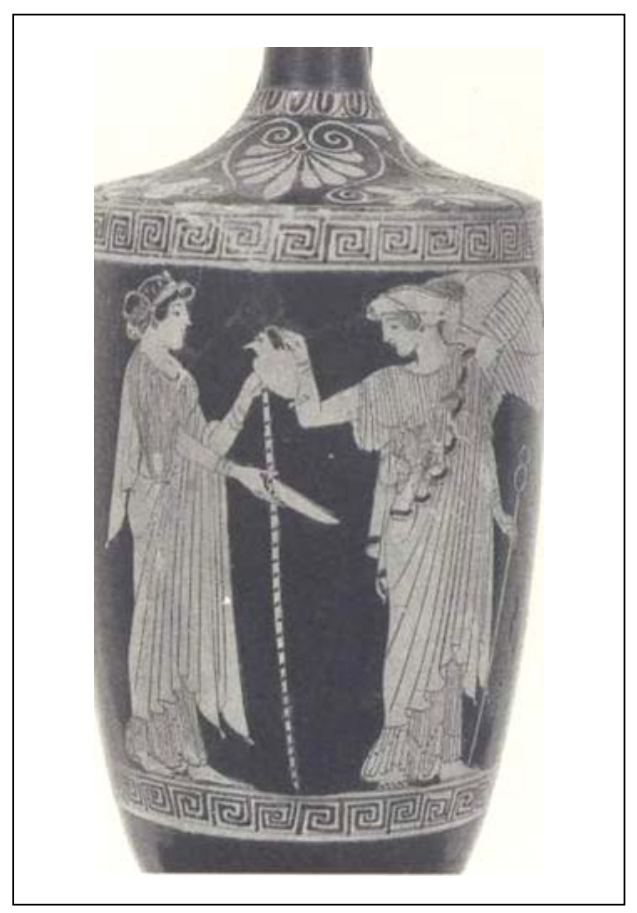




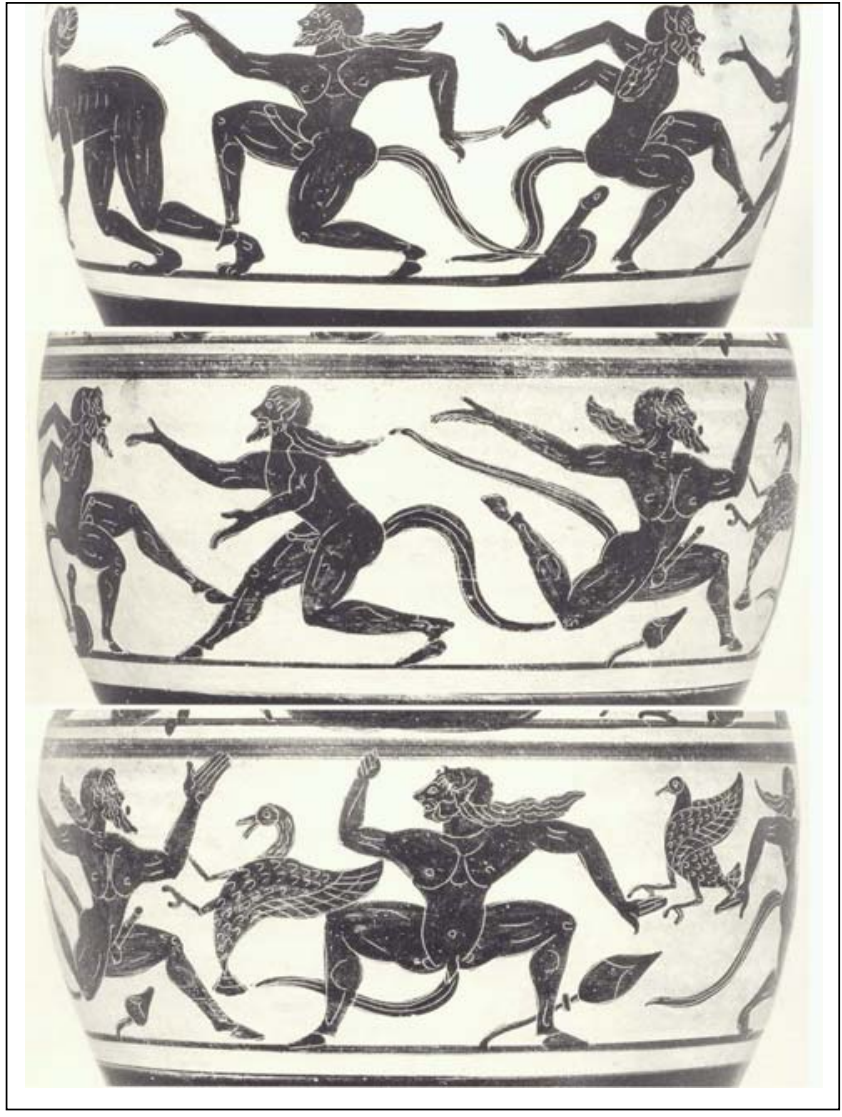

Here too linguistic history affords an important contribution for proper comprehension. The Latin construction "pomum Adami" (Adam's apple) is a literal translation of the Hebrew phrase "tappuach ha adam"; "tappuach" means both protuberance as well as apple while "adam" can be understood as man or person in the generic sense.

In medical circles it was the Swiss anatomist Caspar Bauhin who in 1586 first used the expression "Adam's apple" to refer to the knob on the larynx composed of thyroid cartilage. ${ }^{[1]}$ Shortly thereafter the Dutch physician Gerard Blaes explicitly linked the same expression with the "sign of the sin" which is central to the Old Testament story of Adam. ${ }^{[2]}$ Yet the corresponding Bible story offers a surprise to modern readers. In Genesis $(3,6-10)$ the story reads:

"And when the woman saw that the tree was good for food ... she took of the fruit thereof, and did eat, and gave also unto her husband with her; and he did eat. And the eyes of them both were opened, and they knew that they were naked ... And the LORD God called unto Adam, and said unto him, Where art thou? And he said, I heard thy voice in the garden, and I was afraid, because I was naked; and I hid myself.”
Figure 12. Satyrs. Amphora, circa 510 BC (courtesy of Martin Wagner Museum, University of Würzburg).

There is no apple in this Old Testament story nor is it mentioned that Adam took such a big bite of the forbidden fruit that when he was surprised by God it became stuck in his throat (Figure 13). It was the church fathers and the pious world of the Middle Ages that supplied the botanical specification and an expanded theological interpretation. Only now does the round, cartilaginous protrusion in men's throats call forth the memory of original sin, the "peccatum originale". The Adam's apple has thenceforth signified the conspicuous remains of that "old Adam" which each Christian carries within himself.

Through the end of the $19^{\text {th }}$ century the highly symbolic Adam's apple experienced a veritable storm of usages in vernacular languages. The BNA from 1895, however, preferenced the neutral expression laryngeal prominence - because the convexness is also present in women, though less protrusive than in men. Yet, as so often, common parlance could not be dictated "par ordre de Mufti". The Adam's apple continues to live both in colloquial as well as medical speech, and in the anglicized world list for the $21^{\text {st }}$ century it is once again present. ${ }^{[7]}$ One can only wonder whether in the future Adam's apple will be replaced by the more accurate Adam's bit. 
Figure 13. The Fall of Man. Mosaic from San Marco in Venice, $13^{\text {th }} \mathrm{C}$. (courtesy of the Procuratura di San Marco, Venice).

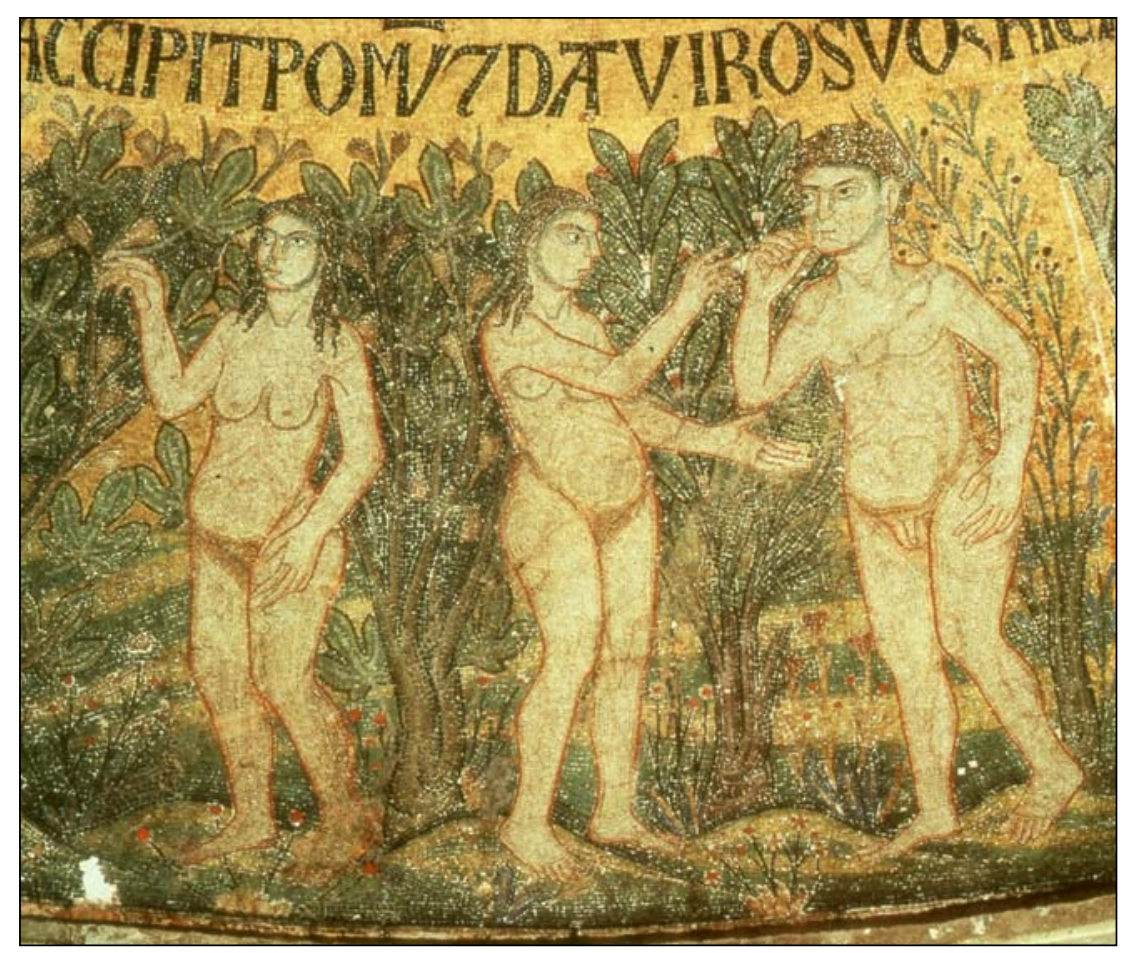

\section{Striking Head Shapes: Greek Cyclops and Roman Janus}

There are close links between an array of human deformities and ancient mythological characters. The requisite analysis of these connections shall, however, be preceded by accounts of a few historical cases. The respective morphological anomalies concern a single organ, a large part of the body or its entirety.

According to Greek legend the Cyclopes belong to those gigantic beings from the world's beginnings. Hesiod described these ancient giants with the following words:

"They were like the gods, but one eye only was set in the midst of their fore-heads. And they were surnamed Cyclopes [Orb-eyed] because one orbed eye was set in their foreheads. Strength and might and craft were in their works." (Theogony, 142-145; see Figure 14)

In contrast, the Homeric Cyclopes of the Odyssey (Book 9) appeared as a wild and brutish pastoral people who lived in caves on an island somewhere at the western edge of the world. Their most well known literary representative was the repugnant Polyphem, a lout who ate several of Odysseus' companions, was then outwitted by the survivors and rendered harmless by being blinded by them.

At the beginning of the $19^{\text {th }}$ century every scientist who systematically investigated congenital anomalies in human newborns had recourse to ancient examples. These researchers needed, f.e., to describe a head characterized by the fusion of the two orbits into a single space and instead of two eyeballs just a single central one near the bridge of the nose. As at that time French scholars dominated the field of teratology, initially expressions such as "cyclocéphalie", "monopsie" and "monophthalmie" were established. ${ }^{[19,20]}$ Only later did cyclopia become prevalent.

The Roman god Janus entered the anatomical vocabulary even earlier. As early as 1680 the expression "Janus leporinus" and by 1701 the adjective "janiformis" were established. To this Isidore Geoffroy Saint-Hilaire added the noun faniceps. He simply linked the stem ianand the binding vowel -i- with the suffix -ceps which was derived from the Latin "caput" and already being used in words such as biceps, triceps and quadriceps. ${ }^{[19]}$

The motif of the two-faced male can be traced by to the mythic first king Janus (Figure 15) who according to legend ruled over ancient Rome in the Golden Age and who secluded himself in neighboring Latium - giving his name to the Roman hill "Gianicolo". The duplication of his cranium made him into the patron of all things with two sides. At that time that included the temporal concepts of the year's beginning and end (hence the first month of the year being "January") and figuratively the conflicting nature of human action which even today is called "Janus faced". 


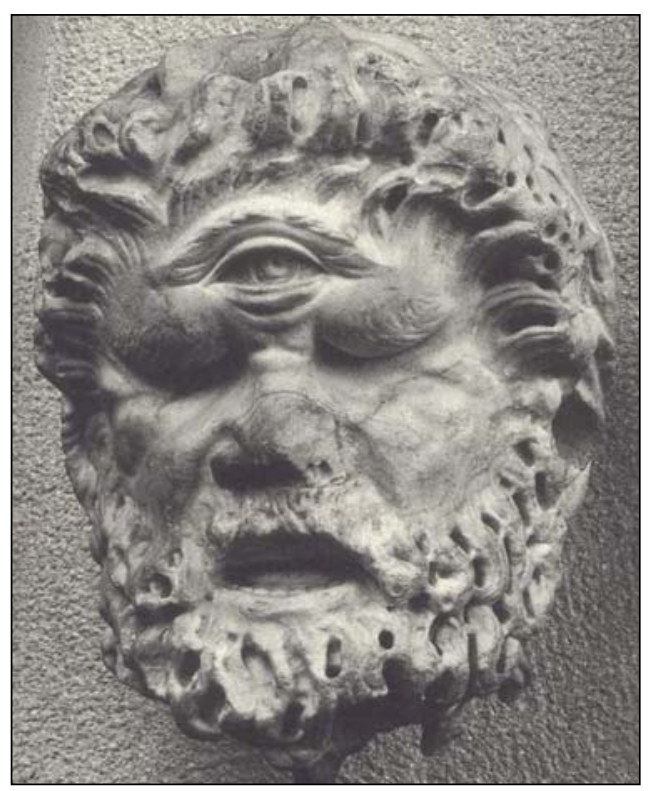

Figure 14. Cyclops. Marble head, circa 150 AD (courtesy Museum of Antiquities, Turin).

\section{The Misunderstanding Regarding the Sirens}

The term sirenomelia is a particularly difficult one. Morphologists understand the term to mean a human deformity which due to a fusion of the caudal extremities into a single unit is associated with a fishtail. In contrast to this, ancient art portrayed the Sirens as birds with female heads, often with arms and breasts (Figure 16).

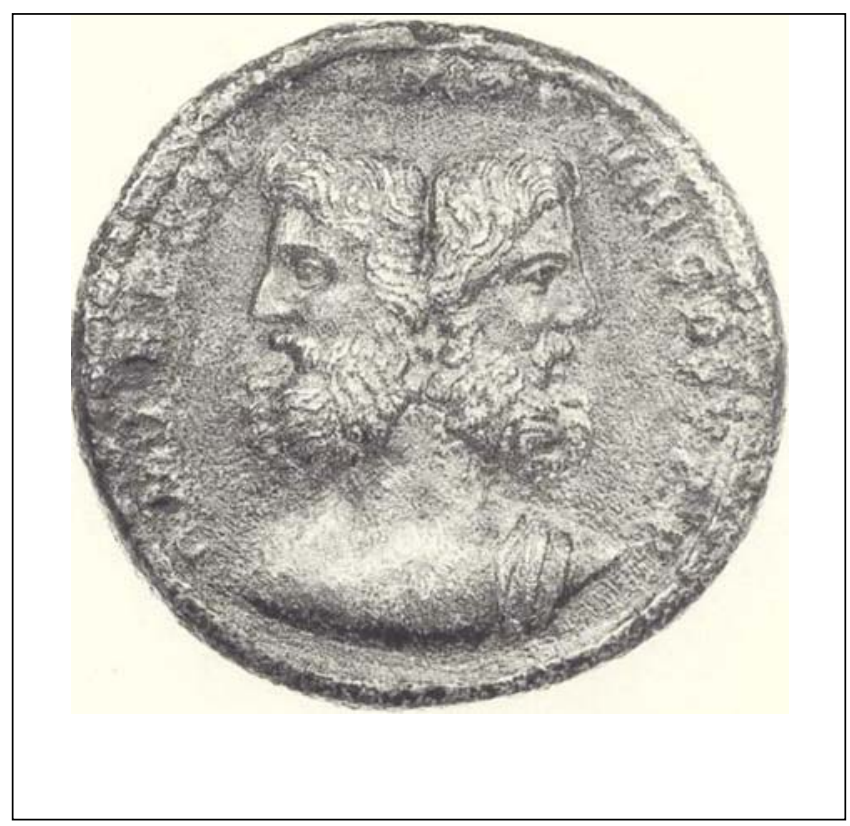

Figure 15. Janus. Medallion from Rome, 187 AD. From Ovid. Festkalender. München: Artemis \& Winkler, 1995.
These composite beings were fabulous monsters who lived on, though not in, the sea. In the Odyssey (Book 12) "the sweetness of their song" was recounted which lured seafarers to their island in order to kill them. But how are we to explain the use of the same term for completely different morphological structures?

The answer to this question lies roughly in the middle of the period between ancient mythology and mod-

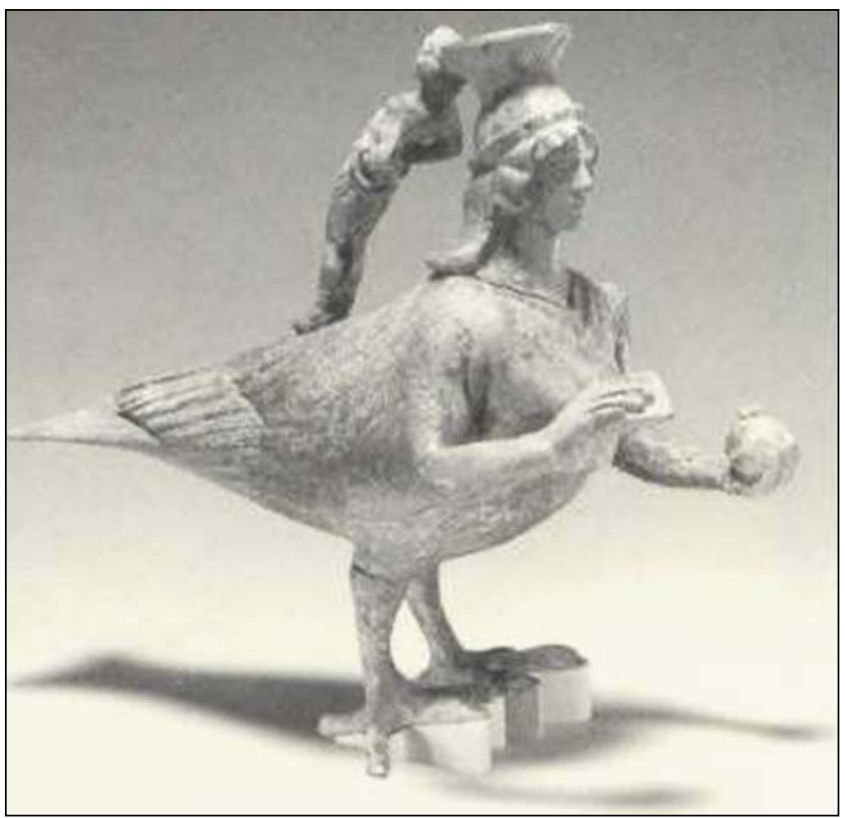

Figure 16. Siren. Vessel, $5^{\text {th }}$ C. BC (courtesy of J. Paul Getty Museum, Los Angeles). 
ern teratology, namely, the Middle Ages, for it was then that the classic siren legend was improperly received such that scholars and chroniclers plainly misinterpreted the bird's tail as a fishtail. ${ }^{[21,22]}$ Evidence for this misperception can be found in Konrad von Würzburg's thirteenth-century "Trojan War" as well as in Konrad von Megenberg's fourteenth-century "Book of Nature" for in both the demonic women exchange their feathers for scales. This is what led to the transformation of the airborne sirens into mermaids and this momentous error was reproduced in illustrated works on ancient mythology and in travelogues. When at the beginning of the $19^{\text {th }}$ century Geoffroy Saint-Hilaire came up with the idea of naming a human anomaly sirenomelia he too tapped into this erroneous tradition. ${ }^{[19]}$ The current teratological term is thus based upon nothing other than a medieval misunderstanding.

\section{An Onomatological and Genealogical Hybrid: Hermaphroditus}

In addition to species border crossers, the myths of many people also include beings composed of both male and female elements. The best known of these in western culture is Hermaphroditus (Figure 17). As the son of the Greek messenger of the gods Hermes and the goddess of beauty Aphrodite, he not only united male and female, but "received a name which is a combination of those of both his parents," as Diodorus noted in the 1st century BC (Bibliotheca historica, 4, 6, 5). The Greek chronicler appended an anatomical-aesthetic characterization: "He has a body which is beautiful and delicate like that of a woman, but has he masculine quality and vigor of man."

The history of the form and the name reflect in a nutshell important milestones in morphological science. Pliny the Elder demystified the existence of hermaphrodites with the remark that the appearance of such forms was classified as an ominous sign of evil in former times; he and his contemporaries saw androgynous beings as nothing but curious natural spectacles (Natural History, $7,3)$ The Renaissance inherited from the Middle Ages an interest in "monsters and marvels"; in his 1573 treatise bearing this title the French surgeon Ambroise Paré also described hermaphrodites with scientific accuracy. At the beginning of the $19^{\text {th }}$ century the medicalization of hermaphrodites was introduced. Once again it was Geoffroy Saint-Hilaire who created the medical category of hermaphroditism: in so doing he established a terminological endpoint and created the basis for modern scientific research.

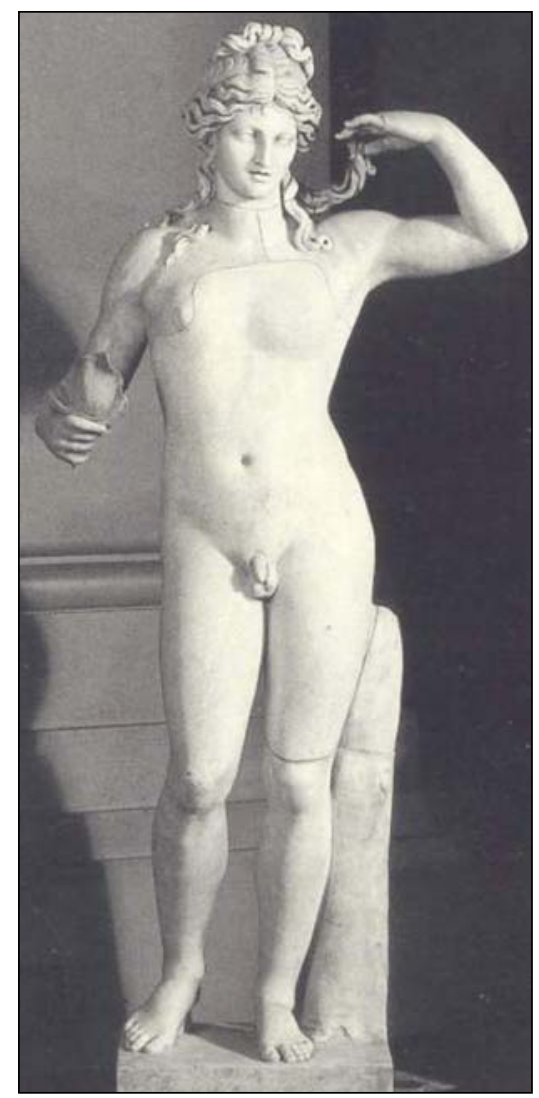




\section{Mythological Figures between Teratoscopy and Artistic Fantasy}

The remarkable parallels between figures from Greek and Roman mythology and certain types of deformations in the descriptions of modern science provoke important questions: Were these mythological figures possibly "constructed" based upon actual human illnesses? Can ancient iconography be at least partially attributed to a real teratoscopy? ${ }^{[23]}$

The answer can be found in differentiating between individual forms. For Janus, the Cyclopes and hermaphrodites it can easily be assumed that the figures were created based upon actual observations, even when ancient representations deviate in certain aspects from clinical morphology. In these cases bringing only the artists' and poets' imagination to account seems less than plausible.

Yet one should not attribute all morphologically marked fantasy forms to human congenital anomalies. ${ }^{[2]]}$ The hypothesis that ancient Atlas represented the reproduction of an encephalocele (Figure 18) or the Centaurs represented human deformations with two additional pedes equini (Figures 19 and 20) arose from purely positivistic interpretative desires of the late $19^{\text {th }}$ century. Twentieth-century historical research has seriously relativized these assumptions. To take only a single example, the Centaurs had been portrayed as barbaric beings in Greek mythology, but are today seen as artistic, literary alternatives to human civilization and no longer as the simple rendering of a rare deformity. Nevertheless, the

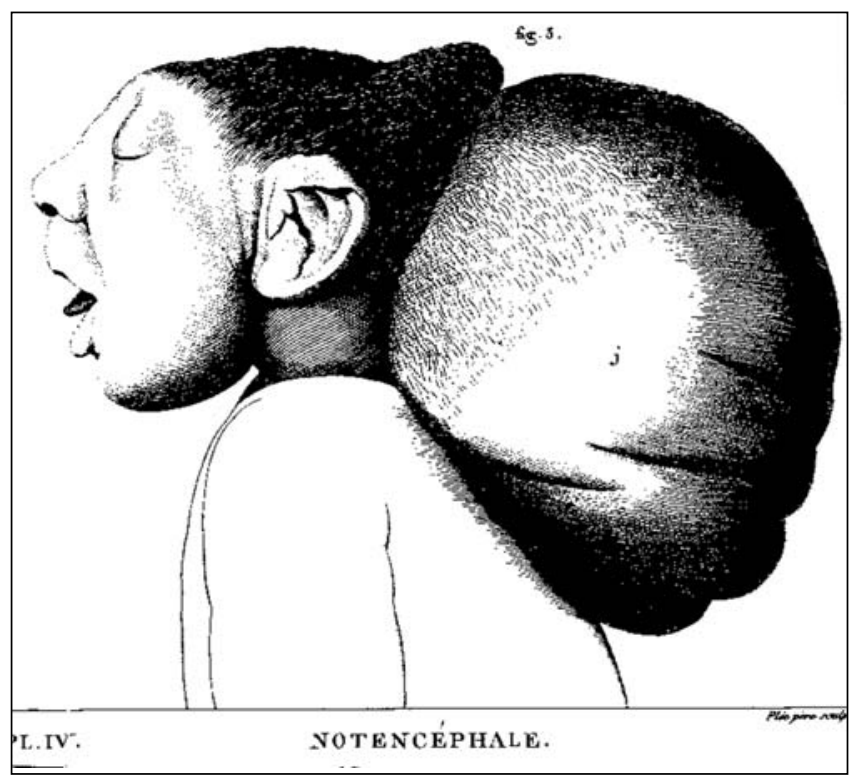

Figure 18. Great Encephalocele on the Rear of the Head. Example for the figure of Atlas? ${ }^{[19]}$ puzzle of poetic discoveries and the realities of pathology are not to be resolved scientifically: the grey prehistory of mythology has no written sources which could decide this question one way or another.

\section{Conclusions}

Between the $16^{\text {th }}$ and $20^{\text {th }}$ centuries more than a dozen figures from Egyptian, Greek and Roman mythology entered anatomical (Table 1) and teratological (Table 2) vocabularies as eponyms. This form of naming accounts for some $0.1 \%$ of anatomical nomenclature and represents a linguistic periphery. Nevertheless, it begs the question: why have several of these eponyms lasted down to the present?

1. Seen as a matter of linguistic economy, most of these one- and two-word expressions are short and thus inherently viable within medical vocabulary. They are essentially more terse than the typical compound expressions of descriptive nomenclature; just compare "atlas" to "prima cervicis vertebra".

2. Anatomical duplicates from mythology have their origins in the same cultural milieu as the rest of the Greco-Latin terminology. For this reason they are not only compatible intrinsically with the rest of medical vocabulary, but also effortlessly assimilated linguistically: a simple genitive attribute such as in tendo Achillis or a suffix such as hermaphroditism.

3. In the Latin scientific culture of the early modern period mythological names represented global players. Thanks to their origin in Greek and Latin such expres-

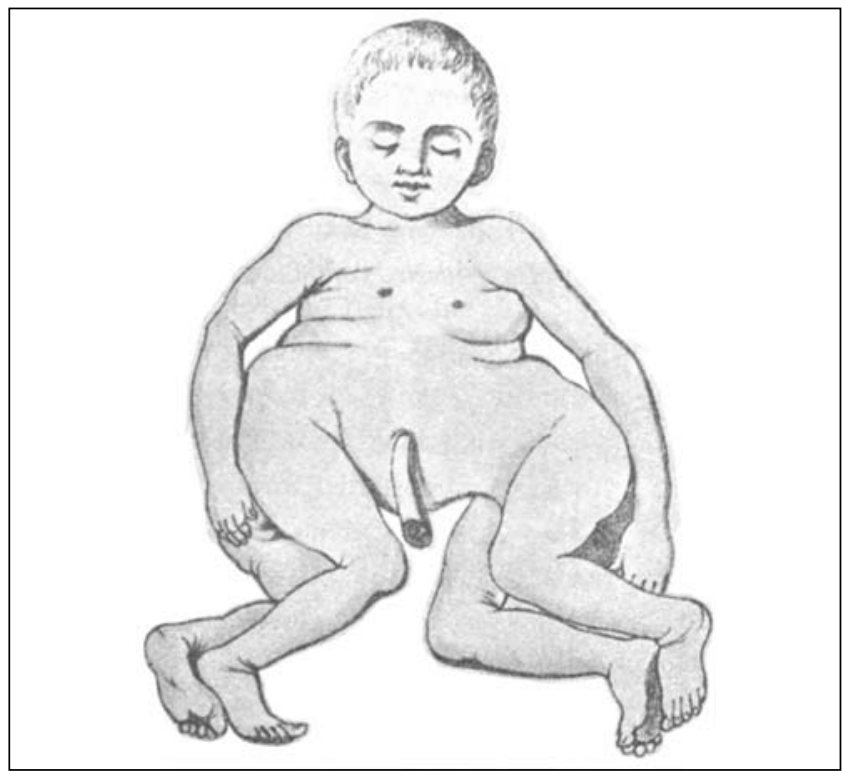

Figure 19. Human deformation with accessory "Pedes equini". Example for the mythological Centaurs? ${ }^{[2]}$ 
Figure 20. Centaur. Hydria circa 480 BC (courtesy Collection of Classical Antiquities, Munich).

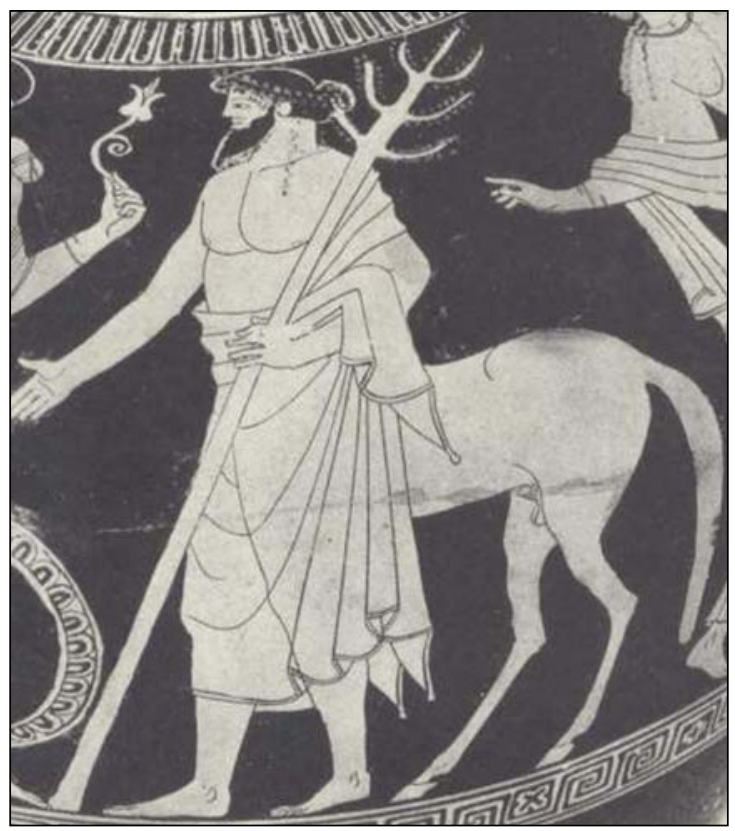

sions continually remained comprehensible across national idioms: Ammon, Atlas and Iris are international heroes.
4. As a rule such mythological symbols have become accepted as technical terms in the fields of anatomy and teratology as they permit distinctive structural analogies.

Table 1

Mythological terms from gross anatomy

\begin{tabular}{|c|c|c|c|}
\hline Legendary Figure & Brief Portrait & Anatomical Term & Date \\
\hline Achilles & Greek Hero at Troy with the vulnerable heel & Achilles tendon* & $17^{\text {th }}$ cent. \\
\hline Amun & Egyptian creation god with curled rams' horns & Ammon's horn* & $18^{\text {th }}$ cent. \\
\hline Atlas & Titan who carries the heavens on his shoulders & Atlas* & antiquity; $16^{\text {th }}$ cent. \\
\hline Cupid & Roman god of love with bow & Cupid's bow & ca. 1960 \\
\hline Hippocampus & Sea-horse und legendary half-horse, half-fish creature & Hippocampus* & $16^{\text {th }}$ cent. \\
\hline Hymen (aios) & Ancient god of marriage who died in nuptial chamber & Hymen* & ca. 1700 \\
\hline Iris & Personification of the rain-bow and divine messenger & Iris* $^{*}$ & antiquity; ca. $18^{\text {th }}$ cent. \\
\hline Nymph & Female demigod water spirit & Lymph*; lymphatic* & $17^{\text {th }}$ cent. \\
\hline Nymph & Female demigod water spirit & Nymph ${ }^{\dagger}$ / Labium minus pudendi & $18^{\text {th }}$ cent \\
\hline Venus & Roman goddess of love & Mons veneris ${ }^{\dagger}$ / Mons pubis & $17^{\text {th }}$ cent. \\
\hline
\end{tabular}

*: listed in Terminologia Anatomica (main part or index of eponyms)

t: not incorporated into the 1895 BNA

Table 2

Mythological terms from teratology

\begin{tabular}{lll}
\hline Legendary Figure & Brief Portrait & Teratological Term \\
\hline Cyclops & Mythical giant with only a single eye & Cyclopia \\
Janus & Double-faced old Roman god & $19^{\text {th }}$ cent. \\
Hermaphroditus & Dual-gendered son of Hermes and Aphrodite & Janiceps \\
Satyr & Male fertility demon with pointed ears & Hermaphroditism \\
Siren & Woman-bird-chimera & Satyr ears \\
\hline
\end{tabular}


This is true for satyr ears and Cupid's bow just as it is for the deformed heads of the Cyclops and Janus. In short, these fictive characters constitute virtually ideal representations.

5. Not least of all, the invention and use of mythological terms reflects the ideal of a broadly educated, humanistic-oriented physician. These appellations integrate innovation based on tradition - an aspiration which has largely been lost today.

Indeed, this final point clarifies the great didactic and intellectual potential the subject of mythology within anatomy offers. On one hand, it lets students become enthused about what is all-too-often perceived to be "dry" anatomical vocabulary with the help of striking word formations. On the other hand, it permits the communication of necessary facts via a presentation of exciting stories linked to excursions into literary, art and medical history. And finally it provides teachers of anatomy the possibility to reference the meaning of cultural traditions in medicine directly from the material they are teaching.

Very soon the question will arise whether future generations of anatomists and physicians will be able to feel the magic of these names. It is thus all the more important to address at least a few of the connections made in this essay during anatomical lessons in order to ensure that anatomists provide a contribution to cultural memory.

\section{Acknowledgments}

David D. Lee assisted with manuscript preparation.

\section{References}

1. Hyrtl J. Onomatologia anatomica. Geschichte und Kritik der anatomischen Sprache der Gegenwart. Wien: Braumüller; 1880. Reprint Hildesheim and New York: Olms; 1970.

2. Barcia Goyanes JJ. Onomatología anatómica nova. Historia del lenguaje anatómico. 8 vols. Valencia: Universidad de Valencia, Secretariado de Publicaciones; 1978-1986.

3. Wain H. The story behind the word. Springfield: Charles C. Thomas; 1958.

4. Rodin AE, Key JD. Medicine, literature \& eponyms. An encyclopedia of medical eponyms derived from literary characters. Malabar: Krieger; 1989.
5. Vons J. Mythologie et médecine. Paris: Ellipses Edition Marketing; 2000.

6. Brunt RJ. Medical eponyms revisited. English Today 1998;54:516.

7. Federative Committee of Anatomical Terminology (FCAT). Terminologia Anatomica. Stuttgart: Thieme; 1998.

8. Lindeboom GA. Dutch medical biography. Amsterdam: Rodopi; 1984.

9. Suy R. Philip Verheyen and his Corporis Humanis Anatomiae. Acta Chir Belg 2007;107:343-54.

10. Liddell HG, Scott R. A Greek-English Lexikon. Oxford: Clarendon, 1996.

11. Taullard JC. "El arco de cupido" desde el punto di vista embriológico. La Semana Médica 1961;118:292-5.

12. Dietz GW, Christensen EE. Normal "Cupid's bow" contour of the lower lumbar vertebra. Radiology 1976;121:577-9.

13. Marcovecchio E. Dizionario etimologico storico dei termini medici. Firenze: Festina Lente; 1993.

14. cf. Berengario da Carpi J. A short introduction to anatomy (Isagogae Breves). Translated by LR Lind. Chicago: University Press; 1959. Reprint New York: 1969.

15. Fischer-Homberger E. Hebammen und Hymen. Sudhoffs Archiv 1977;61:75-94.

16. Lewis FT. The significance of the term hippocampus. J Comp Neurol 1923;35:213-30.

17. De Smet Y. Hippocampe, ver à soie, bélier, hippopotame, dauphin. Le bestiaire de la corne d'Ammon. La Revue du Praticien 1999;49: 2073-5.

18. Olry R, Haines DE. Cerebral mythology. A skull stuffed with gods. J Hist Neurosci 1998;7:82-3.

19. Geoffroy Saint-Hilaire I. Histoire générale et particulière des anomalies de l'organisation chez l'homme et les animaux, 2 vols. Paris: Baillière; 1836.

20. Rême B. Polyphème et la vision monoculaire ou la mythologie avait tout prévu. Archives des Maladies Professionelles 1967;28: 261-2.

21. Gruber GB. Studien zur Historik der Teratologie (Teil I). Zentralblatt für allgemeine Pathologie und pathologische Anatomie 1964;105:219-37 and 293-316.

22. Kleiss E. Über Sirenendarstellungen wahrscheinlich romanischen Ursprungs in einem Südtiroler Kirchlein und über Sirenen im allgemeinen. Ein Beitrag zur Teratologie und ihrer Geschichte in der bildenden Kunst. Gegenbaurs Morphol Jahrb 1968;112:185-212.

23. Schadewaldt H. Orthopädische Aspekte der Mythologie. In: Schlegel KF, ed. Der Körperbehinderte in Mythologie und Kunst. Stuttgart: Thieme; 1983. p. 1-18.

24. Schatz F. Die griechischen Götter und die menschlichen Missgeburten. Wiesbaden: Bergmann; 1901. [Reprint] Amsterdam: Rodopi; 1969. 